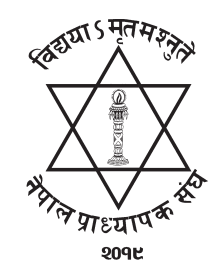

NJ: NUTA

\title{
Impact of Government Policy on Women Empowerment: Evidence from the Poverty Alleviation Fund, Nepal
}

\author{
Susmita Gautam \\ Department of Rural Development, Tri-Chandra Multiple Campus, Tribhuvan University, Nepal \\ Email: susmita.gautam@trc.tu.edu.np
}

\begin{abstract}
Traditionally, most of the women in developing countries like Nepal have had to face different forms of inequality and discrimination such as limited access to education, deprivation from property rights and forced early marriage mainly due to the patriarchal structure of society. As a result, gender disparity, forced marriage and violence against them, women have a lower societal status and lower level of education, few accesses to employment and legal rights compared to male. Government policies and programs helps to improve all the aspects of women empowerment. The main objective is to study the impact of government policy based programme for women empowerment. The study demonstrates the role, responsibility, opportunity, and decision-making issues of women. Taking reference of PAF model for women empowerment members of community organizations (CO) involved were selected as a sample. Both qualitative and quantitative data were analyzed. The PAF model takes community demand driven approach and supports the formation of representative community organizations of the poor and helps them identify their own development priorities, needs and solutions. The findings revealed that the women are in the process of their empowerment. They need position help and support from the family, society, and country as well. For this, country should develop gender friendly policies and programs.
\end{abstract}

Key words: Community organization, gender Equality, poverty alleviation, social inclusion, women empowerment

\section{Introduction}

Since the inception of Women in Development (WID) in Nepal's planned development endeavor during 1980s (after the Sixth Five Year Plan), government has initiated many women targeted programmes in sectors like education, health, and micro-credit for women empowerment. Women empowerment is, mainly in developing and underdeveloped country, a significant topic of discussion. It is a process that leads women to realize their full potential, their rights to have access to opportunities, resources, and choices with the freedom of decision making both within and outside home. Women Empowerment means promoting women in their social and economic development, providing them equal opportunities of employment, education, economic development and allowing them to socialize; the freedoms and rights that were denied before.

NUTA JOURNAL, 7 (1 \& 2), 2020 : ISSN: 2616 - 017x 
Increasing women's empowerment have both intrinsic and instrumental values, leading to economic efficiency and other important development results (World Bank, 2011). Furthermore, empowering women as economic, political, and social actors can change policy choices and make institutions more representative of a range of voices. (World Bank, 2011).

Since empowerment is a multidimensional concept, it is visible at different domains - as the household or the country level - and in different spheres as the political or economic spheres (Maiorano et al., 2016). Consequently, the causes of empowerment are different depending on which domain or sphere to investigate. Specifically, improvement in one dimension or domain does not automatically imply improvement in all dimensions (Pratley, 2016).

Nepal's statistics shows that women's literacy rate, enrollment rate in higher education, involvement in technical and vocational education is lower than men which is due to the social norms and culture of the society. Though, women participation is increasing every year in the decision-making sector. However, significant participation and contribution is yet to be achieved. According to the Nepal human development report, 2015, 26.6 percent women are head of household and 29.5 percent are sets in parliament. There are 17.7 percent of women in at least secondary education level, 79.9 percent women are labor force participation, 25.9 percent of women are human inequality coefficient and 41.4 percent of women inequality in education and 15.1 percent women are inequality in income (UNDP, 2015).

Nepal is a signatory to various national and international declarations for women's development. The Millennium development goals (MDGs, 2000) and convention of the elimination of all forms of discrimination against women (CEDAW, 1978) also focused on the areas of women empowerment.

Nepal Poverty Alleviation Fund (PAF) is a semi-autonomous government agency, created by the Government of Nepal by an Act of Parliament to function as a targeted program of poverty alleviation for marginalized and poor households. The World Bank provides financial and technical support to improve living conditions, livelihoods and empowerment among the rural poor, with particular attention to groups that have traditionally been excluded by reasons of gender, ethnicity, caste and location. Since its launch in 2004, PAF has covered 40 poorest districts of the country, supporting some 15,000 community organizations, and benefiting more than 500,000 households, over 2.5 million people. The two main interventions in PAF are income generating activities (IG) and smallscale village and community infrastructure (INF).

The Poverty Alleviation Fund Ordinance established Poverty Alleviation Fund in 2003 as a specialized institution targeted to. PAF strives to eliminating extreme poverty in a sustainable manner by bringing the excluded communities (women and Dalits) into the mainstream of development and by involving the poor and disadvantaged groups in the driving seat of development efforts in all programs that impact on the livelihood of persons living in poverty. Women empowerment gained considerable leverage under PAF where government of Nepal recognized as a policy issue as one of the important pillars for Poverty Reduction Strategy.

\section{Material and Methods}

The study used a mixed approach for the data analysis. The key impact results were derived from quasi experimental impact evaluation method. The results were later triangulated with the findings from qualitative information. FGD was conducted with the PAF's beneficiaries, for this member of 
community organizations (COs) were selected. Similarly, in depth interview with experts representing PAF's PM and POs who are informed about PAF was conducted for Key Informant Interview (KII).

\section{Results}

The result was analyzed to assess the impact of women targeted programmes on women's economic empowerment through raised income, enhancement of business knowledge and entrepreneurial skills for microenterprises through a multipurpose grant program, and social empowerment through gender equity and equality.

\section{General changes on the members of community organization}

Among different changes reported, individual empowerment, awareness, and confident (47\%) was significant followed by better earning of beneficiary member (34\%) as the impact of PAF program (Table 1). Likewise, better education of family members especially of children (22\%), improved livelihood conditions $(20 \%)$ and family harmony (19\%) were the other changes responded by the respondents.

Table 1 Types of changes reported as intended impacts on members of community organization.

\begin{tabular}{|l|l|}
\hline Responses & Percent (\%) \\
\hline Individual Empowerment, Awareness and Confident & 47 \\
\hline Better Earning & 34 \\
\hline Better Education & 22 \\
\hline Improved Livelihood Conditions & 20 \\
\hline Better Access to Health & 24 \\
\hline Family Harmony & 19 \\
\hline
\end{tabular}

Source: Field survey, 2019

\section{Education}

There is a close relationship between education and awareness about women empowerment. Education is the most important factor for overall development and empowerment of an individual. The level of education is closely related to the other factor like awareness, social values, knowledge etc.

Table 2 Percentage Distribution of Respondents by Educational Status and Level

\begin{tabular}{|l|l|l|}
\hline Educational Status & Number & Percent \\
\hline Illiterate & 1 & 0.8 \\
\hline Literate & 127 & 99.2 \\
\hline Total & $\mathbf{1 2 8}$ & $\mathbf{1 0 0}$ \\
\hline Education Level & \multicolumn{2}{l|}{} \\
\hline Literate (but not schooling) & 17 & 13.4 \\
\hline Primary (1-5 class) & 17 & 13.4 \\
\hline Lower secondary (6-8 class) & 26 & 20.5 \\
\hline Secondary (9-10 class) & 28 & 22.0 \\
\hline+2 Level & 27 & 21.3 \\
\hline Bachelor & 11 & 8.7 \\
\hline Masters and above & 1 & 0.8 \\
\hline Total & $\mathbf{1 2 7}$ & $\mathbf{1 0 0}$ \\
\hline
\end{tabular}

Source: Field survey, 2019 
Almost all the respondents were literate i.e. 99.2\%. Only one respondent had no education. Looking at the level of education, among 128 respondents, 17 were literate with 17, 26, 28 and 27 with primary, lower secondary, secondary and +2 levels, respectively (Table 2). There were only 12 respondents having the education level bachelor and above i. e. 9.5\%. It showed that low population had attended higher level of education. The main cause of not attending higher education level was financial problem, social tradition, and family disagreement. About $91.5 \%$ of respondents had the education level below bachelor's degree.

\section{Health Service Availability}

Health is a state of complete physical, mental, and social well-being and not merely the absence of diseases and infirmities in all matters related to reproductive health and its function and system. It is an important factor for quality of life of people.

Table 3 Percentage Distribution of Respondents by Types of Health Facilities Available in Locality

\begin{tabular}{|l|l|l|}
\hline Types of Health Facility & Number & Percent \\
\hline Hospital & 2 & 1.6 \\
\hline Health post & 84 & 65.6 \\
\hline Private clinic & 42 & 32.8 \\
\hline Total & $\mathbf{1 2 8}$ & $\mathbf{1 0 0}$ \\
\hline
\end{tabular}

Source: Field survey, 2019

The majority of the respondents (84) i.e. 65.6 percent women said that health post was available in their locality, 32.8 percent responded availability of private clinic and only 1.6 percent responded on hospital facility. It indicated that the people of the study area need to go other location for treatment of complicated health problems. However, they had the facility for general health check-up and treatments.

\section{Involvement of women in decision making process}

Decision should be taken among inter and intra family by the women may be one of the parameters of their empowerment. Their involvement process in different activity of decision-making steps encourages them to empower themselves. Some of the parameters are delt below to understand their empowerment.

\section{Household Activities}

Out of 128 respondents, 124 respondents (52\%) were involved in the decision-making issue (Fig. 1). 48\% were involved but sometimes. But it was important that, their opinion was included or not in the decision-making process. The majority of the respondents $(68.0 \%)$ said that both husband and wife took the major decision on the household activities and followed by involvement of family members (16.4\%), husband 'decision (13.3\%) and only 2.3 percent women took the major decision on the household activities (Table 4). It indicated lower level of women participation in the household decision making process. The patriarchal socio-cultural system of the society played the dominant role in the household decision making issues in the research area. 
Fig 1 Respondents included in HHS Decision Making Process

\section{Opinion included in decision making process}

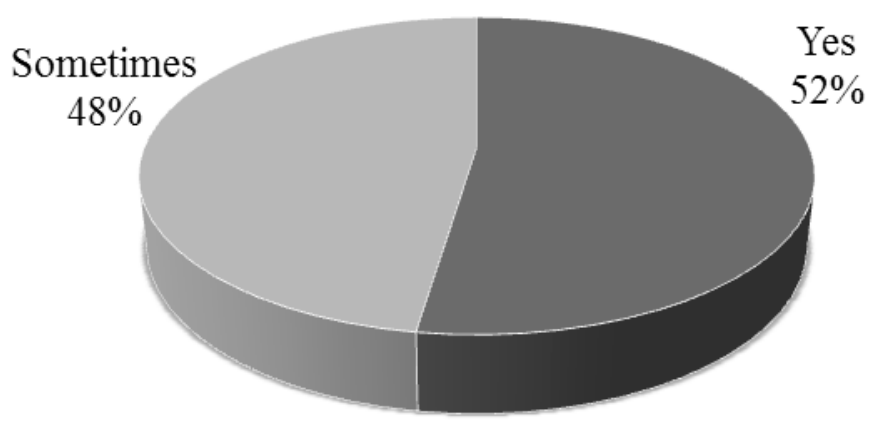

Source: Field survey, 2019

Table 4 Distribution Pattern of Respondents by Major Decision on Household Activities

\begin{tabular}{|l|l|l|}
\hline Decision in HHs & Number & Percent \\
\hline Self & 3 & 2.3 \\
\hline Husband & 17 & 13.3 \\
\hline Both & 87 & 68.0 \\
\hline Family member & 21 & 16.4 \\
\hline Total & $\mathbf{1 2 8}$ & $\mathbf{1 0 0}$ \\
\hline
\end{tabular}

Source: Field survey, 2019

\section{Community Activities}

Most of the women ie, 94.3 percent participated in the social activities and only 5.7 percent participated in the economic activities in the community (Table 5). Social participation of the women in the communities was due to improvement in the women knowledge and attitude towards the different community issues. However, their participation in the economic activities and issues was minimal which needs to be strengthened through acquainting them on their roles in such issues.

Table 5 Percentage Distribution of Respondents on Participation in the Communities Activities

\begin{tabular}{|l|l|l|}
\hline Activities & Number & Percent \\
\hline Social & 100 & 94.3 \\
\hline Economic & 6 & 5.7 \\
\hline Total & $\mathbf{1 0 6}$ & $\mathbf{1 0 0}$ \\
\hline
\end{tabular}

Source: Field survey, 2019 


\section{Women's Empowerment}

Empowerment being multidimensional, social, and political process, people gain control over their own lives, in the society and additionally to the nation. Empowering the women means empowering the society and ultimately the nation. They need to have known about women empowerment. The study revealed that 91 percent of women had the knowledge and acquainted about women empowerment and only 9 percent had never heard the words (Fig. 2). It necessitated that they need the knowledge on women empowerment, its processes and, its impact in family, society and the nation.

Fig. 2. Respondents by Knowledge about Women Empowerment

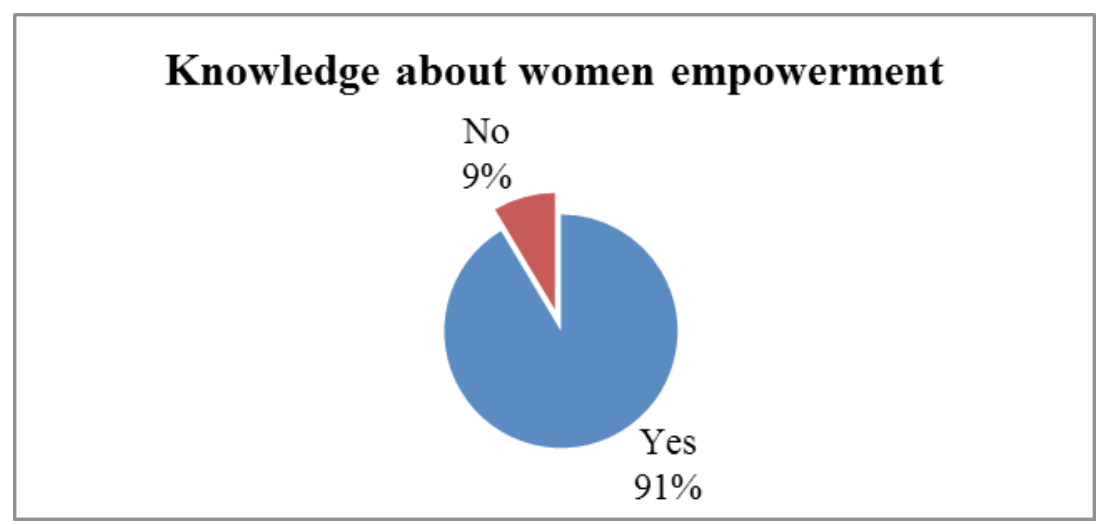

Source: Field survey, 2019

\section{Important Factor for Women Empowerment in the Society}

Different initiatives are necessary for women empowerment. Multiple choices were provided to the respondents to mark the important factors for women empowerment. The majority of the respondents (60.2 percent) said that education was the most important factor of the women empowerment in the society (Table 6). Similarly, 26.6 percent women said that all of the factors (education, employment and health) are important. However, 11.7 percent women said that employment are important factor of women empowerment and only 1.5 percent women said health is most important factor in women empowerment. The study indicated that education was one of the most important factors to empower the women. Moreover, their better health and income generating employment might be crucial factors for further strengthen the empowerment.

Table 6. Percent distribution of respondent's on important factors for women empowerment

\begin{tabular}{|l|l|l|}
\hline Important factors & Number & Percent \\
\hline Education & 77 & 60.2 \\
\hline Employment & 15 & 11.7 \\
\hline Health & 2 & 1.5 \\
\hline All the above & 34 & 26.6 \\
\hline Total & $\mathbf{1 2 8}$ & $\mathbf{1 0 0}$ \\
\hline
\end{tabular}

Source: Field survey, 2019 


\section{Factor for Backwardness of Rural Women}

Backwardness of rural women is a common characteristic in developing countries. There are different causes after it. Backwardness hinders the women to empower them. Their feeling on backwardness needs to be identified and correction must be made to empower them. The study was also objected to understand the factors of backwardness. The study revealed that lack of education $(53.9 \%)$ was the main reason of rural women's backwardness (Fig 3). However, other factors were lack of participation in different societal activities (24.2\%), lack of awareness $(21.1 \%)$ and lack of development activities $(0.8 \%)$ in research area. This is further explained by their views on the obstacles faced during participation in development activities in the society (Table 7).

\section{Fig 3. Percent of Respondents by View towards Women's Backward in Rural area}

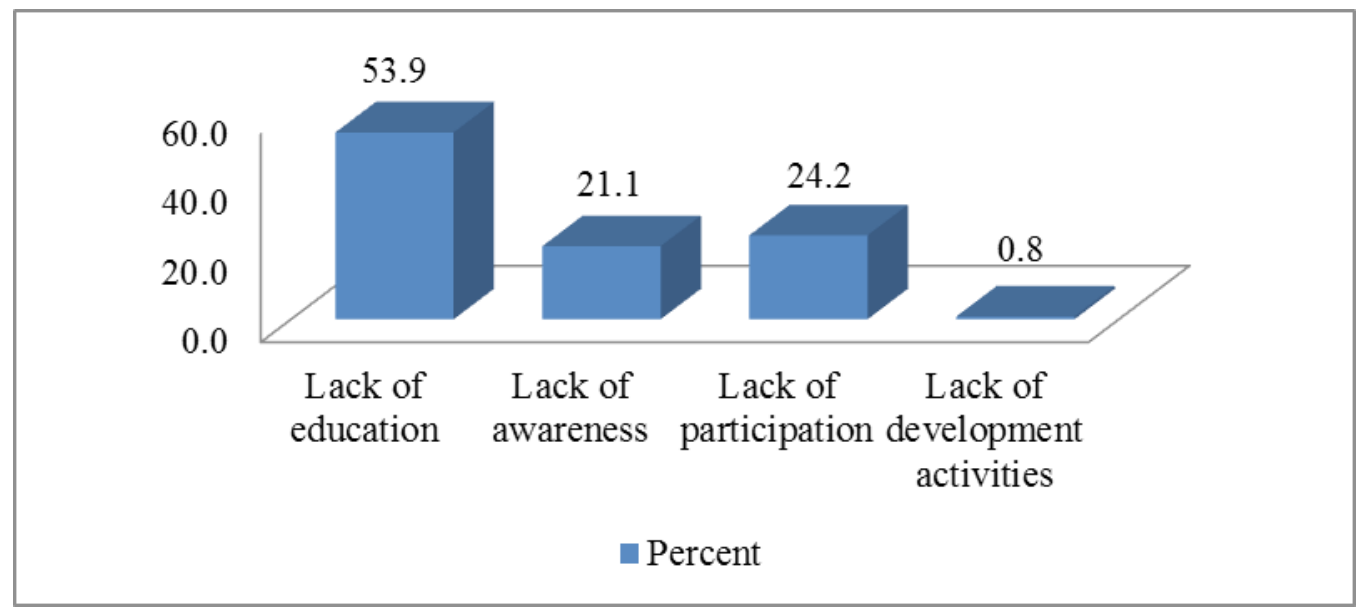

Source: Field survey, 2019

Table 7 Views of Respondents on Obstacles to Women Participation in Development Activities in the Society

\begin{tabular}{|l|l|l|}
\hline Obstacles factors & Number & Percent \\
\hline Lack of education & 58 & 45.3 \\
\hline Lack of equal participation & 31 & 24.2 \\
\hline Lack of family support/encourage & 39 & 30.5 \\
\hline Total & $\mathbf{1 2 8}$ & $\mathbf{1 0 0}$ \\
\hline
\end{tabular}

Source: Field survey, 2019

Participation and inclusiveness have been buzzing words today. But there are several factors that hurdles women from participating in developing activities. Lack of education, male domination, lack of awareness, lack of power, lack of equal participation and unemployment of women are the major reason that deprive women from participation. The data analysis showed that lack of education (45.3\%) was the main obstacles followed by lack of family support/encourage (35.5\%) and lack of equal participation $(24.2 \%)$. It, however, revealed that provision of education to women was most important 
factor to encourage them to participate in the developmental activities in the society. However, they also need support from the family in such activities.

\section{Discussion}

Women in Nepal have long experienced poverty, social exclusion, and marginalization because of their gender, especially among ethnic minorities and low-caste groups. PAF provides a grant to the community organizations to establish and operate the revolving fund. This grant fund is solely operated by the community organization members and used for different activities. The study indicated that there was positive change in individual empowerment, awareness and confident among the $47 \%$ of the members (Table 1). Further, 34 and $22 \%$ of the members responded on better earning and education, respectively. As the size of the revolving fund at community level was substantial, it might not be enough for the demands and the needs of the members. However, due to this substantial revolving fund, high sense of ownership of the program among the beneficiaries had been noticed.

Female had less access to education, occupation, health care, and political participation in the community activities. The female had very low level i.e. only $9.5 \%$ of higher education above bachelor's degree. The facility of healthcare was limited to health-post $(65 \%)$ where only primary healthcare usually provided. The lower access of these activities of women in the society as a result the equality and women condition need to be improved in the country. So that, major attention must be given to the access to services of women as a result equality-based society should established and women condition improved.

Decision making process and the involvement in the process either within the family or in the community is crucial for the livelihood enhancement and developmental activities, respectively. The study showed that only $52 \%$ of respondents were involved in the decision-making process and only $2.3 \%$ could take the self-decision. However, $68 \%$ were noticed the involvement of both the spouses. It revealed that the women are still deprived in the household decisions. This could be because of patriarchal nature of the society. It indicated the domination of male in the household decision making. For the community activities, women decision was high $(94.3 \%)$ in the social activities. But, for the economical activities their participation was minimal i.e., only 5.7\%. Considering that majority of community organization's member were women, it was expected that PAF model help empowered women both economically and socially. Among different factors for women empowerment, 77\% percent felt that education was must to empower them. However, the opportunity of getting employment also empowered them. The study also revealed that lack of education was the major factor for their backwardness the community of rural area. Thus, the impact on education, employment and health can be explained that the member who engaged in income generating activities were able to spend for children's education or seek for the health services at health facilities.

In addition to individual benefits, PAF model also aims to improve the social harmony at community level. There was better working culture in the group, they interact in the meetings, and had better coordination among them. The revolving fund appears as a bonding factor among the group members; hence the 'group dynamics' created spillover effects on social cohesion. The women and Dalit respondents also felt that the response towards them by other members of community had also improved and it was more dignified than ever before. 


\section{Conclusions}

The study shows that women empowerment plays a vital role to gear up the pace of development of a well-cultured and just society. It is said that men and women are like two wheels of a cart; this aphorism cannot be ignored as it exists in the core of reality. Unless women are as able as men, the existing discriminatory laws and disparity hinder women rights. Aptly balanced and richly harmonious social enhancement attributes to women empowerment in Nepal. That's why women empowerment, the key factor to social prosperity, proves to be a must to gear up the acceleration of humanity.

Unfortunately, Nepalese women get fewer opportunities to involve in mainstream of development process due to illiteracy, low status of health, low decision, low rate of economic activities as males, low participation in politics and poverty. No doubt, the demand for modern labor is increasing day by day in both urban and rural areas. However, increase demand for women's labor has been formed doing in agriculture, governmental industries, traditional occupation, and low-price job.

The world is being changed drastically. The women are being succeeded to have the position of president and other higher posts. But, the condition of Nepalese rural women is still not so good. Through, they are aware of their rights, they have not got any freedom and opportunities. They are dominated by their husband, family member and the society as well. The society is not in favor of them for being clever and to participate with male in development activities. The process of women empowerment from the grassroots is difficult but necessary too. In this long process, the traditional concept that has charged for women must be erased and the society should positive towards the empowerment of women.

PAF was established in the context of focused poverty alleviation strategy of the government along with the women empowerment at the time of its inception gives priority on addressing multidimensional poverty among the poor and marginalized population. It has developed, implemented, tested, and professed a special model of poverty alleviation which is inclusive in nature and effective in generating higher level of functionality and ownership of the targeted populations. This model was successful in creating positive impacts at community level.

\section{References}

Acharya, M. (1981). Status of Women in Nepal. Kathmandu: T.U.

Acharya, M. (1994). The Statistical Profile on Nepalese Women. Kathmandu: Institute for Integrated Development.

CBS. (2011). National Population Census. Kathmandu: CBS.

CBS. (2011). Nepal Demographic Health Survey. Kathmandu: CBS.

CBS. (2011). Population Monograph of Nepal. Kathmandu: CBS.

CBS. (2011). VDC Profile. Kathmandu: CBS.

CBS. (2002). Women in Nepal. Kathmandu: CBS.

Dahal, R. (2002). State and Rural Development. Kathmandu: New Hera Books Enterprises.

Parajuli Dilip, Acharya Gayatri (et. al. 2012) Impact of Social Fund on the Welfare of Rural Households: Evidence from the Nepal Poverty Alleviation Fund, South Asia Region, The World Bank.

Regmi Raghav Raj (et. al. 2018) Comprehensive Impact Evaluation (CIE) of Poverty Alleviation Fund (PAF) Nepal, Kathmandu Nepal 
The World Bank. World Development Report 2012: Gender Equality and Development. World Bank Publications, Washington, 2011.

UN. (1995). The Fourth Conference on Women, in Beijing,China. New York: UN.

UNDP. (2005). Empowering women migrant workers. Retrieved 2010, from United National Development Fund for Women East and Southeast Asia: htpp:/www.unifem.org/globalsanner/ index.php

UNDP. (2014). Gender Development Index. Kathmandu: UNDP.

UNDP. (2015). Human Development Report. Kathmandu: UNDP.

UNFPA. (1996). Program of Action. Kathmandu: UNFPA.

UNICEF. (1991). Child and Women in Nepal. Kathmandu: UNICEF.

ADB (1999). Women in Development: Issues, Challenges and Strtegies in Asia and the Pecific. Philippines: Asian Development Bank.

CEDA, (1972). Population Development Policy in Nepal, Internal Working Document CEDA T.U. Constitution (2063). Interim Constitution of Nepal, Government of Nepal, KT

Ministry of Health (1993). Annual Health Report: Department of Health Services, HMG, Kathmandu. Nepal South Asia Center (1998). Nepal Human Development Report, NSAC.

Pierre Pratley. Associations between quantitative measures of women's empowerment and access to care and health status for mothers and their children: A systematic review of evidence from the developing world. Social Science and Medicine, 169:119 - 131, 2016.

Diego Maiorano, Suruchi Thapar-Björkert, and Hans Blomkvist. The paradoxes of empowerment: gendering nrega in the rural landscape of India. Development in Practice, 26(1):127-134, 2016. 